\title{
The World on Television
}

\author{
Market-driven, Public Service News
}

\author{
Øyvind Ihlen, Sigurd Allern, Kjersti Thorbjørnsrud, \\ \& Ragnar Waldahl
}

\begin{abstract}
How does television cover foreign news? What is covered and how? The present article reports on a comparative study of a license-financed public broadcaster and an advertisingfinanced channel in Norway - the $N R K$ and $T V 2$, respectively. Both channels give priority to international news. While the NRK devotes more time to foreign news (both in absolute and relative numbers) than $T V 2$ does, other aspects of the coverage are strikingly similar: The news is event oriented, there is heavy use of eyewitness footage, and certain regions are hardly visible. At least three explanations can be used to understand these findings: the technological platform (what footage is available, etc.) and the existence of a common news culture that is based on ratings and similar views on what is considered "good television". A third factor is that both channels still have public service obligations.
\end{abstract}

Keywords: foreign news, television news, public service

\section{Introduction}

The media direct attention toward events and occurrences in the world, and help to shape our thinking as well as our understanding of these events. The potentially greatest influence can be expected to occur with regard to matters of which we have little or no direct experience. Foreign news is a prime example of an area where most of us are reliant on what the media report. Studies of foreign news have a long tradition (i.e., Galtung \& Ruge 1965) and there is a vast body of literature focusing on the criteria for what becomes news (e.g., Harcup \& O'Neill 2001; Hjarvard 1995, 1999; Shoemaker \& Cohen 2006). In the present article, we compare how two different broadcasters, one publicly funded and one commercial, treat foreign matters. However, both channels have public service obligations to send news broadcasts. Is the way the world is portrayed influenced by the different financial backgrounds and mandates of these channels? We are interested in what kinds of events are covered, in where foreign news is placed in the broadcast, in which regions the channels focus on and in whether, or how, the channels attempt to make the news relevant to a home audience. We are also interested in what type of interviewees and footage the channels use. One assumption might be that the public broadcaster would have more emphasis on foreign news than its commercial competitor (Waldahl, Andersen, \& Rønning 2009). The similarities and differences between the two channels are discussed in light of the literature on news in general and foreign news in particular. 
The next section contains an overview of the Norwegian television landscape. This is followed by a literature review of studies of foreign news, leading to a presentation of our research questions. Next follows a section on methodology, before the findings themselves are presented. The subsequent section contains a discussion of the findings in a broader context, and the paper ends with a conclusion section that sums up the findings and points to further research possibilities.

\section{The Norwegian Television Landscape}

Norway has several television channels, but only two that really matter in terms of news coverage - the state owned $N R K$ and the privately owned $T V 2^{1}$. In 2008, the former had a market share of $32 \%$ and the latter $25 \%$ of the population over the age of $12 .{ }^{2}$ The third largest channel - TVNorge (TV Norway) - had a share of $8 \%{ }^{3}$ Until $1992, N R K$ had a nationwide monopoly on terrestrial television broadcasts. When the monopoly was lifted, TV2 was established and financed by commercials. From its start, this channel has been regulated by a license agreement with the Ministry of Cultural and Scientific Affairs (now Ministry of Culture), and has been given some public service obligations (Østbye \& Aalberg 2008). The most important condition has been that the channel should produce daily news programs that are meant to be an alternative to the news on NRK. The channel should also make programs for "broad and narrow audiences" and "strengthen Norwegian language, identity and culture". ${ }^{4}$ The new channel took the news requirement seriously and from the outset attempted to establish news and current affairs programs that could compete with NRK. Because the main newscast on the latter channel - NRK Dagsrevyen (NRK The Daily Review, authors' translation) - aired at seven o'clock in the evening, TV2 opted to air its own main newscast at nine o'clock p.m. In order to get ahead of $N R K$ with the main news stories, a shorter program was also aired at six thirty p.m. The latter newscast did not, however, establish itself as a true competitor to Dagsrevyen, and today the main two competing news programs are NRK Dagsrevyen and 21-nyhetene (The Nine O'Clock News, authors' translation) (Waldahl, Andersen, \& Rønning 2002).

During its early years, the results of this policy were relatively easy to spot. From the outset, TV2 declared that the channel would emphasize crime-related news (a low priority for the $N R K$ ), while $N R K$ would air more news dealing with foreign affairs. Nevertheless, for other types of stories like the economy, social issues and accidents, there have never been consistent differences between the two channels (Waldahl et al. 2002). Eventually, however, $N R K$ would gradually change its news mix and by 2007 the difference between the two channels decreased markedly, although TV2 continued to heavily feature crime stories (Waldahl et al. 2009).

The domestic part of the television newscasts is, at least in most cases, based on the work of the television channels' own reporters and editorial staff. Concerning foreign news, however, the situation is often different. In most cases, these reports are based on footage and information gathered or licensed from television news agencies, like Reuters Television, that have numerous bureaus around the world. Of special importance for Norwegian and other European broadcasters are the news exchange services operated by such entities as the European Broadcasting Union (Boyd-Barrett \& Thussu 1992; Cohen, Levy, \& Roeh 1996). 
Nonetheless, $N R K$ still has correspondents in major cities and political beats like Brussels, Washington, London, Moscow and the Middle East. By contrast, TV2 has a single foreign correspondent based in the US. From time to time, the channels will send reportage teams to areas of conflict or to catastrophes. However, the costs of keeping permanent correspondents are high, and in many countries foreign correspondents seem to be regarded as "endangered species" (Allern \& Linge 2006).

\section{Literature Review}

In this section, we first give a short overview of the different strands of research on news in general and foreign news in particular. Dominating trends within television journalism will be described, and their possible implications for the profile of private and public broadcasters will be discussed. Against this background, we then develop our research questions.

A long research tradition has aimed at describing the stable characteristics of news in general and foreign news coverage in particular, across countries and media systems. The seminal study by Galtung and Ruge (1965) is still often referred to as the starting point for the studies of news values, and various scholars have followed in their path, pointing to rather fixed aspects of the news, such as a focus on erratic events, unexpectedness, drama, conflict, negativity, proximity and elite persons and nations (Galtung \& Ruge 1965; Harcup \& O’Neill 2001; Peterson 1981). The most recent comprehensive study of news topics in ten countries around the world confirmed the hypothesis of similar news topics across countries: An event is likely to become news if it deals with sports, politics, cultural events, business, internal order or human interest (Shoemaker \& Cohen 2006).

As for foreign news in particular, a comprehensive investigation of international reporting in 29 countries gave results in line with the news values proposed by Galtung and Ruge (Sreberny-Mohammadi, Nordenstreng, Stevenson, \& Ugboajah 1985). According to this study, there is a great focus on political news in the foreign coverage, both regarding political actors and topics, across media systems and countries. There is also a strong tendency to focus on events occurring within, and actors belonging to, the geographical region in which a country is situated. In other words, regionalism is a prominent force in the selection of foreign news. Additionally, there is a tendency to pay attention to the US and Western Europe, and an opposite tendency to overlook or neglect news from Latin American and African countries. When these latter regions do appear as "hot spots" in the news, however, they are most often linked to major disturbances, catastrophes and disasters. Other studies have shown that regionalism is often paired with a nationalistic or ethnocentric framing of the foreign news. Van Dijk, in his analysis of 130 newspapers from 90 different countries, found that there is "a shared global concept of foreign news" and a shared code of practices that lead to a standardized description of events. However, "most of the world's press tends to be nationalistic if not ethnocentric" (Dijk 1988, pp. 130-131).

As a rule, generic news values have to be adapted and forged into an editorial market strategy (Allern 2002; McManus 1994; Tulloch \& Sparks 2000; Østgaard 1965). In Norway as in other European countries, even the public service channels financed by public license fees or taxes face tough competition today. The market ratings of different 
programs - even the newscasts - are important, not least as a legitimating basis for the license fee privileges (Syvertsen 1997).

More recent studies have pointed to trends in the commercialization and popularization of the media as important factors influencing the type and amount of foreign coverage in the news media. Market-oriented and entertainment-centered news media are said to explain why there has been a sharp reduction in the foreign news coverage in the US during the post-cold war era (Schudson \& Tifft 2005). News organizations have increasingly turned to "soft" news programs centered on crime, calamities and accidents (Curran, Iyengar, Brink Lund, \& Salovaara-Moring 2009). These are trends that might influence the status of news in general and foreign news in particular.

So far, however, the ability to produce regular, serious newscasts has proven to be politically important and of high symbolic value for most national and regional television channels. The newscasts represent the link between television as medium and news as an institution (Helland 1995). A television channel without news defines itself outside the field of journalism, ignoring the ascribed and idealized roles of the news media as channels of information, public debate and scrutinizers of those in power. The increased pressure for revenues and high audience rating might, however, prove to change the content of the "contract" between broadcasters and society as a whole. For all channels seeking a wide national audience, geographical and cultural proximity - and the possibility of national framing, that is, the ability to present the news in a way that makes it relevant in a particular nation - would be expected to gain importance.

For public service broadcasters - with a mandate to inform and educate the audience and a financial basis of state subsidies and license fees - the focus on soft news and tabloid narratives would be expected to be less prominent than in commercially based television. In line with this expectation, Curran and colleagues (2009) find that public service television in Denmark and Finland devotes more attention to international news than do the market-based broadcasters in the US and Britain. While the latter study seems to confirm a divergence hypothesis, other studies have found evidence of convergence. In a large-scale study of NRK and TV2 (Waldahl et al. 2002), the authors used the metaphor of looking at two railroad tracks that seem to meet in the horizon. Looking closer, however, the tracks run in parallel. The point is that the two channels have created their own news concepts, which they develop, but that these are variations within a standard theme. Both channels are influenced by technological developments, not least the possibility to report live on air. As mentioned in the previous section, the channels also have to abide by the same media regulation requiring a daily news program. Another important factor is that the channels have to rely on some common sources, e.g. Reuters. Furthermore, it seems important to mention that $T V 2$ recruited its news staff from $N R K$ and other established news media, thus contributing to the transfer of an established news culture.

A follow-up study (Waldahl et al. 2009) confirmed many of the findings described above. In addition, the authors pointed to the increased importance of the technological development, for instance the ability to broadcast a dialogue between the news anchor and the reporter in the field. Furthermore, journalists at both NRK and TV2 are now part of integrated news desks and are expected to deliver content to several programs and several platforms (i.e., the Internet and for the radio channels of NRK). This development has led to further convergence between the two channels, according to Waldahl and colleagues (2009). 
Following Blumler and colleagues (1989), we can distinguish between different journalistic approaches to news production. Concerning television news, the first to be mentioned is the 'sacerdotal approach'; political processes are viewed as crucial to democracy and, therefore, as important per se. Consequently, the news agenda is guided by the agenda of political institutions and procedural events, like referendums, negotiations and political elections. On the other hand, we find the 'pragmatic approach', demanding that institutional political events must compete for space and time with any other news item, including accidents, crime reports and major sports events. A third, 'conventional journalistic approach' is dominated by commercial and 'tabloid' news values, giving priority to events laced with conflict, drama and human emotions of interest to a broad, mass public.

Historically, the 'sacerdotal approach' has been associated with public service broadcasting and serious newspapers, while the 'conventional approach' has been seen as typical of popular newspapers and commercial television oriented toward the 'sensational'. The 'pragmatic approach' can then be seen as a compromise and a competition between the two former types, representing a tendency toward stronger market competition, while still somewhat influenced by traditional news values and democratic obligations.

The central question behind this study, then, is whether there is a significant difference between the amount of foreign news and the way it is covered on the two main Norwegian broadcasters: the public channel based on license fees, known as $N R K$, and the private and commercial channel, TV2. Against this background, we have formulated the following research questions.

RQ1: How much foreign news is there on NRK Dagsrevyen and TV2's 21-nyhetene and where is the foreign news placed in the broadcast?

RQ2: What are the themes of the news items?

RQ3: Which countries and regions are covered?

RQ4: Is there a Norwegian link, and if so, how is this constructed?

RQ5: What kinds of interviewees are used?

RQ6: What kind of footage is used?

\section{Method}

In order to answer the research questions posed above, the main newscasts on the public service broadcaster $N R K$ and the commercial $T V 2$ were recorded during the period September 17-December 16, 2007. A research assistant first test coded a sample of one week of foreign news items according to a predefined coding scheme with variables relevant to the research questions. This led to some changes. Then the assistant watched all the newscasts and isolated the foreign news items. This resulted in a total sample of 714 items that were subsequently coded. We will use this sample to say something about Norwegian television news in general, although we are aware that our research sample may have a bias toward particular events (and hence actors, regions, etc.) in this particular period. Hence, we are most interested in the comparison between the coverage of the two channels in this period. 
To measure reliability, a second research assistant coded every tenth item until a $10 \%$ sample of the total was reached. Two measures for coder agreement were then used, first the relatively liberal percent agreement and next the more conservative Cohen's Kappa (Lombard, Snyder-Duch, \& Campanella Bracken 2002). Using this combination of measures of reliability, we discarded some of the original variables. Only the variables that had substantial agreement scores $(0.61)$ or above on Cohen's Kappa were included along with those that had a percentage agreement of 0.824 or above. Two exceptions were made, for "theme" $(0.635)$ and "interviewee" $(0.756)$, as both of these variables had substantial agreement scores using Cohen's Kappa (0.744; 0.756).

Percentages have been calculated based on the number of stories, thus, the findings are not weighted with regard to the length of the story itself. The length did, however, influence the coding of stories that contained several topics. In these instances, the research assistant made a qualitative interpretation as to what should be called the main topic of the story. This was not always a straightforward decision.

\section{Findings}

RQ1: How much foreign news is there and where is this placed in the broadcast? The newscast on NRK was on average 26.0 minutes long, while TV2 had newscasts that were on average 16.0 minutes long. This goes some way in explaining that the number of foreign news items in the sample is disproportionate: The NRK sample consists of 400, while the sample from $T V 2$ has 314 items. Turning to relative numbers, however, shows that foreign news gets more attention from $N R K$. The average time this channel devoted to foreign news was 10.37 minutes or almost $40 \%$ of the newscast in the period. $T V 2$, on the other hand, apportioned an average of 5.13 minutes or almost $32 \%$ to foreign news. A major finding is thus that, relatively speaking, both the public service and the commercial channel air a fair amount of foreign news. A similar finding can be ascertained in other studies, both focusing on Norwegian (Waldahl et al. 2009) and Swedish news (Jönsson \& Strömbäck 2007). Both of these studies showed that $60 \%$ of the television news concerned internal affairs.

The majority of the foreign news on both channels ( $40 \%$ and $39 \%$ for $N R K$ and $T V 2$, respectively) was located in the last part of the newscast (see Table 1). NRK, however, also placed a substantial amount (35\%) of the foreign news in the first part of the newscast, as compared to TV2, which placed $25 \%$ of the foreign news in the first part.

Table 1. Placement in Newscast of Foreign News

\begin{tabular}{llrrrr} 
& & 1 part & 2 part & 3 part & N \\
\hline NRK & Count & 141 & 98 & 161 & 400 \\
& $\%$ & 35 & 25 & 40 & 100.0 \\
TV2 & Count & 78 & 113 & 123 & 314 \\
& $\%$ & 25 & 36 & 39 & 100.0 \\
Total & Count & 219 & 211 & 284 & 714 \\
& $\%$ & 31 & 30 & 40 & 100.0 \\
\hline
\end{tabular}


Compared to findings from other countries, like the US (Schudson \& Tifft 2005), the Norwegian channels air a great deal of foreign news. Looking at the situation in Finland and Denmark, the tendency for the public broadcaster - in this case $N R K$ - to air more foreign news than its commercial competitor is to be expected (Curran et al. 2009). On the other hand, conflicting evidence also exists: Looking at the four evening newscasts of NRK and TV2, Waldahl and colleagues (2009) found no huge differences between the channels in this respect.

\section{RQ2: What are the themes of the news items?}

For both television channels, "dramatic/violent events" (including civil unrest, riots, accidents, disasters, military action, terrorism and military risk) is the most predominant theme (32\%) (see Table 2). Most of this coverage was focused on a high level conflict in Burma, when the military junta quashed democracy rallies. The second largest category was tied to constitutional politics, including elections, political meetings, and state visits (15\%). The third largest category was crime and corruption (10\%). The other categories - environment and health; culture, entertainment, sports; internal political affairs; and economics and trade - were all smaller categories.

Table 2. Themes in the Foreign News Coverage (percentage)

\begin{tabular}{lrrr} 
Theme & NRK & TV2 & Total \\
\hline Dramatic/violent events & 31 & 34 & 32 \\
Constitutional politics & 17 & 14 & 15 \\
Crime, corruption & 8 & 12 & 10 \\
Environment and health issues & 8 & 8 & 8 \\
Culture, entertainment, sports & 7 & 5 & 6 \\
Internal political affairs & 6 & 7 & 6 \\
Economy and trade & 6 & 4 & 5 \\
Other issues & 14 & 11 & 12 \\
SUM & 100 & 100 & 100 \\
$\mathrm{~N}$ & 400 & 314 & 714 \\
\hline
\end{tabular}

The emphasis on topics in this category is in line with findings showing how crime, calamities and accidents are often large categories in the news in general, and how this is linked to the commercialization and popularization of the news (Curran et al. 2009; Gripsrud 1992). It is interesting to note that the news mixture described above is strikingly similar to the news mixture found in the popular press (Allern 2002). It must be noted, however, that TV2 airs sports news in a separate segment, and that NRK has its own program devoted to foreign news - Urix (a "poetic" Norwegian abbreviation for foreign affairs) - although this is not aired during prime time.

Looking at differences between the two channels, we can see that there is a slight tendency for $N R K$ to place more emphasis on constitutional politics, while TV2 somewhat favors a 'conventional journalistic approach' (Blumler et al. 1989), looking for dramatic and violent news, as well as stories on crime and corruption. This difference is in good accordance with expectations regarding the likely difference between a commercially financed channel and a traditional public service channel like $N R K$ (e.g., Curran et al 
2009). The differences for the remaining categories - environment and health; culture, entertainment and sports; internal political affairs; economics and trade - were smaller and fell within one or two percentage points.

However, all together the differences between the channels are small and the main conclusion is that a 'pragmatic journalistic approach' (Blumler et al. 1989) to foreign news seems to predominate on both $N R K$ and $T V 2$. Institutional political events must compete for space and time with other news items, including accidents, crime reports and other dramatic events. However, some influence of the "sacerdotal approach" can still be found. For example, constitutional politics - a topic not traditionally considered "exciting" - was nevertheless the second largest category of foreign news on both channels.

\section{RQ3: Which countries and regions are covered?}

Almost a fifth of the foreign news coverage can be tied to Norway (see Table 3), casting Norwegians or Norwegian companies in a prominent role. This category included, for instance, the activities of the oil company Statoil abroad. This finding corresponds well with the classic news criterion of proximity (Galtung \& Ruge 1965).

Table 3. Most Frequently Covered Countries (percentage)

\begin{tabular}{lrrr} 
Countries & NRK & TV2 & Total \\
\hline Norway & 19 & 20 & 19 \\
USA & 10 & 11 & 10 \\
Burma & 10 & 10 & 10 \\
Pakistan & 6 & 9 & 7 \\
Russia & 5 & 7 & 6 \\
Denmark & 4 & 5 & 5 \\
UK & 4 & 3 & 3 \\
Sweden & 3 & 3 & 3 \\
Turkey & 3 & 2 & 3 \\
Indonesia & 3 & 2 & 2 \\
France & 3 & 1 & 2 \\
Ukraine & 1 & 2 & 2 \\
Afghanistan & 1 & 2 & 2 \\
SUM & 100 & 100 & 100 \\
N & 400 & 314 & 714 \\
\hline
\end{tabular}

One golden rule behind judgments of newsworthiness is that the closer to home an event takes place, the more will it evoke the interest of the audience. A somewhat modified version of this rule is the creation of connections between an event that takes place far away and a domestic setting. It appears as if this news frame is actively used by both $N R K$ and $T V 2$ in their foreign news production.

A lot of attention was also devoted to US news, which made up over a tenth of the coverage. In addition, however, the aforementioned unrest in Burma was also high on the agenda. Next on the list were Pakistan and Russia. The neighboring countries Sweden and Denmark were covered relatively often, and Pakistan, Turkey and Indonesia 
also stood out. Of the 192 members of the United Nations, the two Norwegian channels covered 73 countries during the research period.

Looking at regions, a relatively surprising result was the predominance of news covering Asia (see Table 4). This result is partly explained by the unrest in Burma that garnered much attention, but a huge international environmental conference in Indonesia also helped to boost the numbers. The Nordic region made up over one fourth of the coverage, with the rest of Europe taking a close second. Combining the two latter categories, it becomes evident that over half of the coverage is centered on Europe. Just as interesting is the fact that the combined coverage of Latin America, Africa and Oceania amounted to just seven percent of the total coverage $(\mathrm{N}=714)$. This, however, is in line with research from other countries (Sreberny-Mohammadi et al. 1985).

Table 4. Coverage According to Region (percentage)

\begin{tabular}{lrrc} 
Region & NRK & TV2 & Total \\
\hline Asia & 33 & 32 & 33 \\
Nordic region & 27 & 29 & 28 \\
Europe (excluding the Nordic region) & 22 & 22 & 22 \\
USA-Canada & 10 & 11 & 10 \\
Africa & 4 & 3 & 4 \\
Latin America & 2 & 2 & 2 \\
Oceania & 1 & 1 & 1 \\
SUM & 100 & 100 & 100 \\
$\mathrm{~N}$ & 400 & 314 & 714 \\
\hline
\end{tabular}

As to the significance of the findings on inclusion and exclusion of different regions and countries in the foreign news at TV2 and NRK during this period, however, some caution is required. Even if large quantities of newscasts are analyzed here, the results are necessarily influenced by the particular period we study. Focusing on other periods of the year would likely have yielded different results. Typical examples of this are the high level of news from Burma in the research period and the fact that the Middle East and the conflict between Israel and Palestine were nearly absent. The latter conflict has been a mainstay in Norwegian media and politics. The months after our research period showed that Burma fell back to its more regular modest role in the eye of the Norwegian broadcasters, whereas the situation in the Middle East led to a massive focus in the beginning of 2009. Of greater interest than the focus on single countries during this period, then, is the great similarity between the two broadcasters in their focus on particular countries and regions of the world. As shown in Table 4, the difference between NRK and TV2 hovers in the area of one percentage point or below, in other words, the coverage is almost identical.

The similarities are most striking regarding the coverage of Asia. The exceptions are that TV2 reports more from Pakistan and Russia than NRK does, while the reverse is the case regarding Turkey, Indonesia and France. There is a slight tendency for TV2 to focus more on the Nordic region, while NRK has more news from Africa. Nevertheless, these tendencies do not preclude the picture of two broadcasters that, in spite of a competitive rather than cooperative relationship, have journalists who make the same 
news judgments when selecting their focus on different regions and countries. As we shall see, the similarity between the broadcasters does not stop with their geographical focus: Often "foreign news" will have both a foreign and a domestic component; they are framed in ways that make them more relevant to a national or local audience (Cohen et al. 1996).

\section{RQ4: Is there a Norwegian link and if so, how is this constructed?}

While some of the material in the sample has been classified as "Norwegian foreign news," a Norwegian link is often evident in the rest of the sample as well. First and foremost, the news items feature Norwegian politicians. Over a tenth of the items include a Norwegian politician (see Table 5). Two other examples of the construction of a Norwegian link included focusing on a Norwegian business $(6 \%)$ and focusing on Norwegian aid and development (3\%).

Table 5. Norwegian Link in the Coverage (percentage; the categories are not exclusive)

\begin{tabular}{lrrr} 
& NRK & TV2 & Total \\
\hline Norwegian politician & 11 & 15 & 13 \\
Link to domestic news story & 12 & 7 & 10 \\
Norwegian business & 8 & 5 & 6 \\
Norwegian aid and development & 3 & 3 & 3 \\
Other Norwegian actor & 3 & 1 & 2 \\
SUM & 100 & 100 & 100 \\
N & 400 & 314 & 714 \\
\hline
\end{tabular}

In order to create flow in the program, the anchor often announces a link between the foreign news item and a national news item (Cohen et al. 1996). An example might be, "That was the financial crisis in the US, but here at home we also feel the consequences, as we now will see at the Oslo Stock Exchange." A tenth of the items are linked together and followed by a national news item this way.

There were some minor differences between $N R K$ and $T V 2$, first and foremost that the former more frequently used links to a domestic news story (12\% versus $7 \%$ ). TV2, however, used Norwegian politicians to a larger extent than NRK did (15\% versus $11 \%)$.

\section{RQ5: What kinds of interviewees are used?}

Sixty-two percent of the items contained interviews. The main interviewee on both NRK and TV2 was a man (58\% and $67 \%$ males, versus $42 \%$ and $33 \%$ females; $\mathrm{N}=263$ and 181, respectively). Still, this figure is lower than that indicated in other research (Waldahl et al. 2009). The relative number of female interviewees, especially on NRK, is significantly higher than that found in Norwegian and international studies of news sources in newspapers (Allern 2001)

The largest single category that was used was "eyewitness/victim/man in the street" $(30 \%, \mathrm{~N}=444)$, followed by "politician/state leader/cabinet member" $(12 \%)$ and "expert" ( $9 \%$ ). NRK had the largest portion of the former category (33\% compared to $26 \%$ for 
$T V 2, \mathrm{~N}=263$ and 181 , respectively) but also of the latter ( $10 \%$ compared to $7 \%$ for $T V 2$, $\mathrm{N}=263$ and 181, respectively).

\section{RQ6: What kind of footage is used?}

The coverage is overwhelmingly based on location footage and almost $96 \%$ of the news items on both channels relied on this type of footage. Almost a fifth of the items in the research period contained dramatic footage from riots or clashes between protesters and police or the military $(19 \%$ on the $N R K ; 16 \%$ on TV2). There was a slight tendency for $T V 2$ to included less footage and to instead air dramatic nature pictures or curiosity footage. Nonetheless, the latter two picture types did not make up huge categories.

Our findings are in good accordance with a perspective regarding the demand for live images as an extra and predominant television news factor that is often difficult to satisfy. To be "good television," a news story must be told through dynamic and interesting footage (Sand \& Helland 1998). Allern and Linge (2006) demonstrate this phenomenon by quoting a senior reporter in $N R K$ who explains that the lack of news about the EU is due to the predominance of "static pictures of elderly men in dark suits" in reports about the organization. The reporter added that whenever material available from the Eurovision Broadcast Union (EBU) can be described as "dull talking heads on a podium," the pictures are of little interest to most viewers and have no chance of being selected by the desk editor (Allern \& Linge 2006, p. 130).

\section{Discussion}

The two largest Norwegian television channels devoted between 32 and $40 \%$ of their main newscasts to foreign news. In other words, Norwegian viewers are treated to a great deal of foreign news, relatively speaking. Can a reason for this international focus be that Norway has an economy that is largely dependent on the international economy? Or does the international orientation mirror what traditionally has been an activist policy line from Norwegian governments? These and other questions would be interesting to probe further.

NRK provides more foreign news than TV2 does, both in terms of absolute length of the foreign coverage and in terms of the length of the single news reports. Even so, the differences in content of the news are minor. The news is often negative and eventdriven. The two broadcasters generally focus on the same countries and regions, and highlight the same type of events. These findings are telling, as they indicate that the journalists and editors at the two channels make the same judgments about what kinds of world events are newsworthy. For instance, almost a fifth of what we here have called "foreign news" still focuses on Norway abroad or the like. Quite often, the items bring in a Norwegian link, either by focusing on Norwegian politicians or by trying to tie the foreign news item together with a domestic news item.

The foreign news is largely Eurocentric, with the exception of US news. Violent riots in Asia and a high level environmental conference in Indonesia, however, are considered newsworthy enough to merit coverage. Huge regions and continents like Latin America and Africa seemingly did not have any such stories to offer during the 
research period, and hence they remained largely uncovered. We notice, however, that $N R K$ has twice as many reports from Africa compared with TV2, which indicates that the larger correspondent network of $N R K$ to some extent affects the coverage of certain regions and events.

There is an emphasis on location footage, preferably dramatic, and the channels typically interview male eyewitnesses or victims. For the most part, the stories are built on a conflict frame. But even if both broadcasters focus on politics and commerce, as well as culture broadly defined, the foreign news in Norway is dominated by dramatic events, disasters, unrest and riots. This is particularly the case when the news relates to Asia, Africa and Latin America. The coverage of Burma is a case in point.

Despite some minor differences between the two channels, the similarities between them are the most striking finding. Looking only at the different channel types, public service versus commercial, this finding may come across as a bit of a surprise. Some studies have described $N R K$ as more "serious" and more concerned with what has been characterized as important news - such as politics and the economy - than its commercial counterpart. Influential journalists in $N R K$ were, in line with this picture, highly critical of the popularized news production in $T V 2$ in the first years after the NRK monopoly was lifted (Sand \& Helland 1998). Internal disputes about the character of programs on $N R K$ dominated the organization during these years. Those arguing for a focus on audience ratings came out on top in this debate (Ytreberg 1999). In line with this tendency, newer studies have underscored the popular orientation that now predominates on NRK (Thorbjørnsrud 2009). The clear-cut focus at $N R K$ on audience ratings may make the Norwegian public service channel more market oriented as compared with public service channels in other countries, even if a commercialization process has affected the program policy of most of broadcasters in Europe (Hallin \& Mancini 2004). A comparison between the arguments behind the program policy at the Swedish public service broadcaster $S V T$ and at $N R K$ indicates that it may be worthwhile to explore such a hypothesis further: Whereas the direction in $N R K$ points to the imperative of winning the ratings war, the goal at $S V T$ is to make high quality programs and to uphold the standard of the programming of a model public service broadcaster like $B B C$ (Larsen 2008). Since 1992, high ratings have been seen as the key to legitimizing the public service broadcaster $N R K$. This has led to convergence toward a common journalistic culture that causes journalists to consider the same matters newsworthy and the same aspects interesting from a journalistic point of view. In addition, the technological platform and production demands stemming from this may outweigh other considerations. In this sense, our findings are also consistent with those of earlier Norwegian studies (Sand \& Helland 1998; Waldahl et al. 2002, 2009).

\section{Conclusion}

One of the main objectives of the establishment of a private broadcaster competing with $N R K$ was to give the audience a true alternative to the newscasts of NRK (Waldahl et al. 2002). The present study, like several others, has shown that this goal has hardly been achieved. Whereas there were some marked differences between the broadcasters in the first decade of competition, convergence between the two broadcasters seems to have erased much of the initial variation. Foreign news is not an exception to this rule, as our 
findings demonstrate. The foreign news reports on both channels generally appear to be produced according to the same news judgments.

There are several reasons for this convergence. Foreign news is a well-established genre, building on stable conventions across countries. Our findings of a strong regional bias, as well as a national link in the foreign news provided by both $N R K$ and $T V 2$, are examples of the application of such conventions.

Both broadcasters take part in the same technological development, with digitalization being the most important element. "Liveness" is required in modern television production, creating a dependence on international news and photo agencies. This applies to both $N R K$ and TV2. There also seems to be evidence of "true" convergence, in the sense that both channels have adjusted themselves to each other. $N R K$ has copied the more popular news journalism and focused on the "liveness" that has dominated the news on TV2 from the start. The channels also experience increased competition from newspapers that air live pictures on their website, something that may contribute to the development described above.

Additionally, $N R K$ has been preoccupied with ratings as a premise for its legitimacy as a privileged license holder. Until now, $T V 2$ has had some public service obligations as the basic premise for its concession, an obligation that has constrained the broadcaster's freedom in terms of prioritizing foreign news. In December 2009, the channel decided to apply for a new concession, but the conditions have yet to be negotiated. It is only possible to speculate on whether we will see changes relating to the news programs in the future.

Taken together, these factors lead us to our main conclusion: Public service obligations, news culture and technology trump the importance of the economic basis of the channel, whether it is a license-financed or an advertising-financed channel. This seems to hold true, at least in the Norwegian setting. The shared perspectives should also be seen in light of the fact that the news is produced in a homogenous society in which cultural, social and economic differences are small. The end result is nonetheless that the world looks pretty similar on both channels. To get alternative perspectives, viewers have to look elsewhere.

Some limitations of the present study are obvious: It would be fruitful to research whether our findings hold up during a different research period. A follow-up study could research a similar period in a different year. Will there be another high-level conflict - like Burma - that predominates the coverage of both channels? Or do the channels diverge when no such event is underway? Given the centrality of live footage, it would also be interesting to explore in more depth the role news agencies play in the construction of foreign news. Finally, our data have been limited to textual output, whereas a qualitative probing of the producers and the journalists, using either interviews or ethnographic methods, would give insights into the thinking that goes on concerning what constitutes "good television."

\section{Notes}

1. TV2 is owned by the Danish media corporation Egmont (50\%) and the Norwegian media corporation A-pressen (50\%).

2. The market shares for NRK1 and TV2 concern only their main channels. If we include the side channels $N R K 2$ and $N R K 3$, the state-owned channel's market share was 37.7 percent. If we include the side channels TV2 Zebra and TV2 News channel, the market share of TV2 was 29.4 percent. 
3. http://medienorge.uib.no/english/?cat=statistikk\&medium=radio\&queryID=219, accessed June 30, 2009.

4. http://www.tv2.no/omtv2/faq/konsesjon-2003-2009-1652038.html, accessed December 6, 2009.

\section{References}

Allern, S. (2001) Nyhetsverdier: Om markedsorientering og journalistikk i ti norske aviser [News values: On the market orientation and journalism in ten Norwegian newspapers]. Kristiansand: Norway: IJforlaget.

Allern, S. (2002) 'Journalistic and Commercial News Values: News Organizations as Patrons of an Institution and Market Actors', Nordicom Review(1-2), 137-152.

Allern, S., \& Linge, U. (2006) 'The Case of Norway, in AIM Research Consortium (Ed.) Understanding the Logic of EU Reporting in the Mass Media: Analysis of EU Media Coverage and Interviews in Editorial Offices in Europe (pp. 123-136). Bochum: Projektverlag.

Blumler, J.G., Gurevitch, M., \& Nossitier, T. (1989) 'The Earnest Versus the Determined: Election Newsmaking at the BBC' (1987), in I. Crewe \& M. Harrop (Eds.) Political Communications: The General Election Campaign of 1987. Cambridge: Cambridge University Press.

Boyd-Barrett, O., \& Thussu, D.K. (1992) Contra-flow in Global News: International and Regional News Exchange Mechanisms. London: John Libby.

Cohen, A.A., Levy, M., \& Roeh, I. (1996) Global Newsrooms, Local Audiences: A Study of the Eurovision News Exchange. Luton: University of Luton Press.

Curran, J., Iyengar, S., Brink Lund, A., \& Salovaara-Moring, I. (2009) 'Media System, Public Knowledge and Democracy: A Comparative Study’, European Journal of Communication, 24(1), 5-26.

van Dijk, T.A. v. (1988) News as Discourse. Hillsdale, NJ: L. Erlbaum Associates.

Galtung, J., \& Ruge, M.H. (1965) The Structure of Foreign News', Journal of Peace Research, 2(1), 64-91.

Gripsrud, J. (1992) 'The Aesthetics and Politics of Melodrama', in C. Sparks \& P. Dahlgren (Eds.) Journalism and Popular Culture (pp. 84-95). New York: Sage.

Hallin, D.C., \& Mancini, P. (2004) Comparing Media Systems: Three Models of Media and Politics. New York: Cambridge University Press.

Harcup, T., \& O’Neill, D. (2001) 'What is News? Galtung and Ruge revisited', Journalism Studies, 2(2), 261-280.

Helland, K. (1995) Public Service and Commercial News (No. 18). University of Bergen: Department of Media Studies.

Hjarvard, S. (1995) Internasjonale tv-nyheder [International tv news]. Copenhagen: Akademisk Forlag.

Hjarvard, S. (1999) Tv-nyheder i konkurrence [Tv news in competition]. Copenhagen: Samfundslitteratur.

Jönsson, A.M., \& Strömbäck, J. (2007) TV-journalistik i konkurrensens tid: Nyhets- och samhällsprogram $i$ svensk TV 1990-2004 [TV-journalism in the age of competition: News and current affairs programs in Swedish televison 1990-2004]. Stockholm: Ekerlids förlag.

Larsen, H. (2008) 'I demokratiets tjeneste: Offentlig debatt om allmennkringkasting i Norge og Sverige' [In the service of democracy: Public debate about public service broadcasting in Norway and Sweden], Tidsskrift for samfunnsforskning (3), 313-342.

Lombard, M., Snyder-Duch, J., \& Campanella Bracken, C. (2002) 'Content Analysis in Mass Communication: Assessment and Reporting of Intercoder Reliability’, Human Communication Research, 28(4), 587-604.

McManus, J.H. (1994) Market-driven Journalism: Let the Citizen Beware? Thousand Oaks, CA: Sage.

Peterson, S. (1981) 'International News Selection by the Elite Press: A Case Study', The Public Opinion Quarterly, 45(2), 143-163.

Riegert, K. (1998) “Nationalising” Foreign Conflict: Foreign Policy Orientation as a Factor in Television Newsreporting. Stockholm: University of Stockholm, Department of Political Science.

Sand, G., \& Helland, K. (1998) Bak TV-nyhetene: Produksjon og presentasjon i NRK og TV2 [Behind the television news: Production and presentation in the NRK and TV2]. Bergen, Norway: Fagbokforlaget.

Schudson, M., \& Tifft, S.E. (2005) 'American Journalism in Historical Perspective', in G. Overholser \& K.H. Jamieson (Eds.) The Press (pp. 17-28). Oxford: Oxford University Press.

Shoemaker, P. J., \& Cohen, A. (2006) News Around the World: Content, Practitioners, and the Public. London: Routledge.

Sreberny-Mohammadi, A., Nordenstrengt, K., Stevenson, R., \& Ugboajah, F. (1985) Foreign News in the Media: International Reporting in 29 Countries. France, Paris: Unesco.

Syvertsen, T. (1997) Den store TV-krigen: Norsk allmennfjernsyn 1988-1996 [The big TV-war: Norwegian broadcasting 1988-96]. Bergen, Norway: Fagbokforlaget. 
Thorbjørnsrud, K. (2009) Journalistenes valg: Produksjon - interaksjon - iscenesettelse: Møtet mellom journalistikk og politikk $i$ en valgkamp med fokus på NRK Fjernsynets valgformater [A journalistic choice: Production - interaction - construction: The meeting between politics and journalism during an election campaign period] (PhD dissertation). Oslo, Norway: University of Oslo.

Tulloch, J., \& Sparks, C. (2000) Tabloid Tales: Global Debates over Media Standards. Lanham, MD: Rowman \& Littlefield.

Waldahl, R., Andersen, M.B., \& Rønning, H. (2002) Nyheter først og fremst: Norske tv-nyheter: Myter og realiteter [News first and foremost: Norwegian television news: Myths and realities]. Oslo, Norway: Universitetsforlaget.

Waldahl, R., Andersen, M.B., \& Rønning, H. (2009) TV-nyhetenes verden [The world of television news]. Oslo, Norway: Universitetsforlaget.

Ytreberg, E. (1999) Allmennkringkastingens autoritet: Endringer i NRK Fjernsynets tekstproduksjon, 19871994 [The authority of the public service broadcasting: Changes in the text production of the NRK television, 1987-1994] (Dr.art. dissertation). Oslo: University of Oslo.

Østbye, H., \& Aalberg, T. (2008) 'Media and Politics in Norway', in J. Strömbäck, M. Ørsten, \& T. Aalberg (Eds.) Communicating Politics: Political Communication in the Nordic Countries. Gothenburg: Nordicom.

Østgaard, E. (1965) 'Factors Influencing the Flow of News', Journal of Peace Research, 2(1), 39-63.

ØYVIND IHLEN, Dr.art., Professor, Department of Communication, Culture and Languages, Norwegian School of Management BI, oyvind.ihlen@bi.no

SIGURD ALLERN, Dr.polit., Professor, Department of Media and Communication, University of Oslo, sigurd.allern@media.uio.no

KJERSTI THORBJØRNSRUD, Post.Doc., Research Fellow, Department of Sociology and Political Science, Norwegian University of Science and Technology, Trondheim, kjersti.thorbjornsrud@samfunn.ntnu.no

RAGNAR WALDAHL, Dr.philos., Professor, Department of Media and Communication, University of Oslo, ragnar.waldahl@media.uio.no 
